\title{
An empirical interrogation of the Christian/Muslim inter-religious challenges in Northern Nigeria $^{1}$
}

\author{
Oholioabs D. Tuduks \\ Gombe State University, Nigeria \\ tuduks2013@gmail.com
}

\begin{abstract}
Various researches indicate that Christians and Muslims in Northern Nigeria experience a tense and violent relationship that arises from a dysfunctional relationship embedded in a superiority/inferiority complex, discrimination, exclusion, and marginalization. The crisis has created deep-rooted trauma that has caused the two religious groups to co-exist in fear and suspicion. The dysfunctional relationship continues to propagate exclusive and discriminative lifestyle, and triggers tension and violence among Christians and Muslims in the region. This article uses an empirical study approach to engage in an investigation of the experience of Christian/Muslim co-existence in Northern Nigeria. The data collection method of interview was used in drawing the in-depth contextual experience of the people. Findings reveal challenges of Christian/Muslim co-existence, with alarming violence that continues to threaten inter-religious co-existence. Healing and reconciliation were recommended for creating inter-religious functional relationships among the Christians and Muslims in Northern Nigeria.
\end{abstract}

\section{Keywords}

Christian/Muslim co-existence; Northern Nigeria; dysfunctional relationship

1 The essay is extracted from my PhD dissertation submitted to the Faculty of Theology (2019), Stellenbosch University. In view of the methodology of practical theological interpretation used in writing the dissertation, the article presents the descriptiveempirical task with finding and discussion. It also explains how the finding will further be utilized in addressing the other tasks (interpretation, normative and pragmatic) of the methodology. 


\section{Introduction}

Christians and Muslims constitute the major religious groups in Nigeria. The former dominates the southern part, while the latter prevails in the north among the dominant Hausa/Fulani ethnic group. This research concentrates on the state of inter-religious relationship among the two religious groups in the northern part of the country referred to as "Northern Nigeria". ${ }^{2}$ The regional political entity of Northern Nigeria during the postcolonial period was initially broken up into six states in 1967, then ten in 1975 and seventeen in 1991 . $^{3}$ Today, Northern Nigeria has 19 states out of the 36 of the Federal Republic of Nigeria and hosts the Federal Capital Territory (Abuja). Northern Nigeria is divided into three geo-political zones: North-West (with seven states), ${ }^{4}$ North-Central (with six states and the Federal Capital Territory) ${ }^{5}$ and North-East (with six states). ${ }^{6}$

2 The term "Northern Nigeria" identifies a region that was formerly referred to as the "Protectorate of Northern Nigeria" founded in 1900 along with the Protectorate of Southern Nigeria during the British colonial era (see figure 1). There were three British colonial protectorates with Lagos colony as the third protectorate which was formed earlier before Southern and Northern protectorates. Later the Lagos colony was merged with Southern Nigerian Protectorate in 1906. In 1914 the protectorates were amalgamated having the central headquarters of the unified government in Lagos. After the amalgamation, the former protectorates became provinces. By 1960, Nigeria achieved her independence from the British colonial administration thus becoming a sovereign state maintaining Lagos as the country's capital city until 1991 when it was relocated to Abuja.

3 Yusufu Turaki, The British colonial legacy in Northern Nigeria: A social ethical analysis of the colonial and post-colonial society and politics in Nigeria (Jos: Challenge Press, 1993), 6.

4 (1) Kebbi, (2) Sokoto, (3) Zamfara, (4) Kaduna, (5) Katsina, (6) Kano, and (7) Jigawa.

5 (1) Plateau, (2) Benue, (3) Nasarawa, (4) Kogi, (5) Kwara, and (6) Niger.

6 (1) Bauchi, (2) Gombe, (3) Borno, (4) Yobe, (5) Adamawa, and (6) Taraba. 


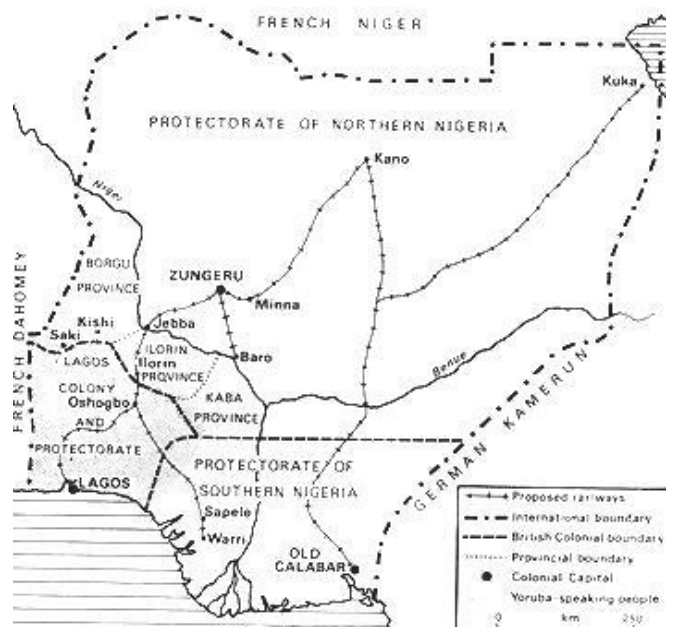

Figure 1: The Protectorates of Northern and Southern Nigeria (The Nigeria 1914 Amalgamation n.d.) by the 234 Project. (https://the234project.com/wp-content/uploads/2017/03/Map-of-Nigeriabefore-the-1914-Amalgamation-showing-the-Three-Protectorates.jpg)

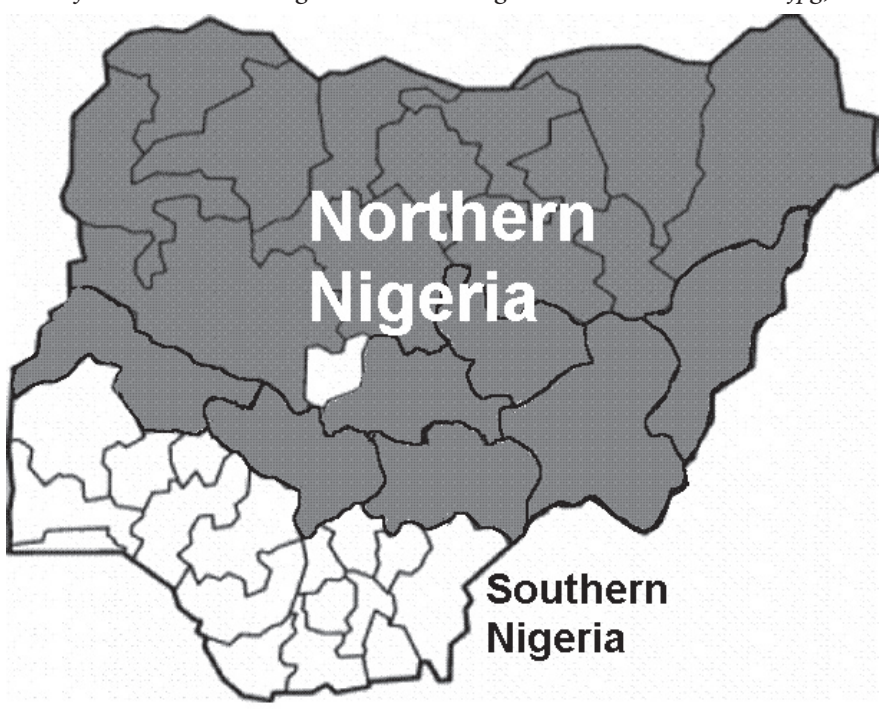

Figure 2: Map of Northern Nigerian region. (c) 2015 Nigeria Infopedia. https://www.nigerianinfopedia.com/list-of-northern-states-in-nigeria/ 
The region of Northern Nigeria is known and mostly described with religious crises that started from 1980 to as recent as 2018 as indicated by much research. ${ }^{7}$ In view of research theoretically conducted on the state of Christian/Muslim relationship, the article argues for the need of an empirical study to investigate the in-depth experience of the people with a view of making a recommendation.

\section{Literature survey}

The region of Northern Nigeria has experienced periodic religious crises that have caused a lot of havoc among Christians and Muslims. According to research, the reality of the religious crises began in 1980 and continued periodically with claims of lives and property. ${ }^{8}$ The religious crises are often categorized in two different stages. The first stage is described as the early stage from 1980 to 2008, and the second began from 2009 with the advent of the Boko Haram (BH) attacks to the present. The second stage is also known as the late stage. The early stage of the religious crisis started in 1980 through 1985 by an Islamic group called Maitatsine, ${ }^{9}$ which was believed to have caused catastrophic havoc among Christians and Muslims

7 For example, Isaac Terwase Sampson, "Religious violence in Nigeria: Causal diagnoses and strategic." African Journal on Conflict Resolution 12, no. 1 (2012):107-112; cf. O.D. Tuduks, 2018. (Dis-)continuity of Colonial Religious Identities: A Challenge for Christian/ Muslim Coexistence in Northern Nigeria, in D. Kusa, (ed.), Identities in Flux Globalization, Trauma, and Reconciliation (Bratislava: Kritika \& Kontext, 2018), 184.

8 Shadrack Best, "Religion and religious conflicts in Northern Nigeria." University of Jos Journal of Political Science 2, no. 3 (2001); Cf. "Arne Mulders, Crushed but Not Defeated: The Impact of Persistent Violence of the Church in Northern Nigeria" (Open Doors and Christian Association of Nigeria, 2016). Available from: https://www.opendoorsuk.org/ about/how-we-help/advocacy/nigeria-report-12 [20 April 2019).

9 The activities of the "Maitatsine" were seen and interpreted by some people as an attempt at the Islamic reformation of moral laxity and the political exploitation of the masses by the Muslim leaders of Northern Nigeria, as well as an expression of disagreement with the corruption and the rule of the dictatorship in the northern states. Others saw them as an attack on materialism and modernity and a revolt against all authority in Nigeria, be it Islamic or not; this limited the "Maitatsine" attack not only to Muslims, but also to all the beneficiaries of the material products of the West (Sodiq, "Can Muslims and Christians live together peacefully in Nigeria?", 669). But as to why Christians became the victims of these revolts, Sodiq suggested that Christians were the agents of the West, and therefore invariably seen as the agents of oppression against Muslims and their religion, either directly or indirectly (Ibid., 669). 
but more especially the former. ${ }^{10}$ From 1987 to 2008, the religious crises continued periodically with Christian/Muslim clashes as a result of religious intolerance, exclusion and discrimination, religious solidarity, and alleged blasphemy.

The late stage from 2009 to present started with the emergence of $\mathrm{BH}$; the attack first targeted Christians ${ }^{11}$ and some government institutions. Afterwards, the attack included Muslims as well. ${ }^{12}$ Before the late stage period, the religious crises have been tagged with various nomenclatures informed by the causes of the conflicts. For example, Sharia crisis (2000), Osama Bin Laden's riots (2001), Miss World Pageant crisis (2002), Prophet Mohammad Cartoon riots (2006). ${ }^{13}$ The names tagged to the crises indicated the causes that resulted in violence. For example, the Sharia crisis was triggered by the desire for implementation of sharia law in Northern Nigeria, which Christians protested. Osama Bin Laden riots were caused by some Muslims' act of solidarity with him. The Miss World Pageant crisis was triggered by Muslims' protest in opposing the intended hosting of the pageant in Nigeria. The pageant was later relocated to London due to resistance and protests. The Prophet Mohammad Cartoon riots were as a result of opposition to the cartoon drawn in Denmark of the prophet, to which the Nigerian Muslims released their anger through rioting.

Religious conflicts have been prevalent all over the region as stated above. And have become a recurring event since the 1980 s. $^{14}$ There is virtually no state of the 19 northern states in Nigeria that have not been affected

10 Ibid.

11 According Yushau Sodiq, "whenever any sect of modern revivalism of Islam attacks Westerners or denounces modern materialism, these movements always assume that Christians are agents of the West. Therefore, Christians are directly or indirectly seen as agents of oppression against Islam and Muslims. This might be the reason why some Muslims attacked Christians and their places of worship (Ibid., 669.).

12 Bitrus argues that the involvement of Muslims in Boko Haram's attack is designed to blindfold the public from perceiving the reality of the Boko Haram's mission against Christians. He explains that Muslims are also attacked because they are perceived as threat to Boko Haram's mission and or perceived as collaborators with government to fight against them (Bitrus, "The Persecution of the Church in Northern Nigeria," 383).

13 Gwamna, Religion and politics in Nigeria, 54-62.

14 Abdu, Clash of identities, 220. 
by religious crises. ${ }^{15}$ Arguing about the causes of the inter-religious crises, Yakubu Joseph \& Rainer Rothfuss indicate that Christians in Northern Nigeria have been occasionally subjected to mob attacks from the Muslims as a result of alleged provocation. ${ }^{16}$ Gwamna further stresses that the alleged provocations made Christians in Northern Nigeria suffer attacks from Muslim groups. ${ }^{17} \mathrm{He}$ asserts that some of the crises are so-called "misplaced aggression" for example the Osama Bin Laden riots (2001), the Miss World Pageant crisis (2002) and the Prophet Mohammad Cartoon crisis (2006) which were not perpetrated by Northern Nigerian Christians. In this context, Northern Nigerian Christians were made scapegoats of perceived atrocities in the West who are identified as being Christians. ${ }^{18}$ This misplaced aggression has made the Christians in the region suffer violent attacks and killings in response to these alleged blasphemies. ${ }^{19}$

Inter-religious violence promotes a state of dysfunctional relationship with a superiority/inferiority complex. The violence and the dysfunctional relationship continue to alternate themselves. This state has been confirmed in the works of Turaki (1993), ${ }^{20}$ Best (2001), ${ }^{21}$ Omotosho (2003), ${ }^{22}$ Sodiq

15 Sampson, "Religious violence in Nigeria”, 107-112.

16 Joseph and Rothfuss, “Threats to religious freedom in Nigeria”, 79-80.

17 Gwamna, Religion and politics in Nigeria, 64-66.

18 Griswold, "Christian-Muslim encounters in Nigeria on the fault line", 23.

19 For examples, in Niger state, Methodus Chimaije Emmanuel on the 29 May 2016 was killed over alleged blasphemous comments about Prophet Mohammed on the social media (Omonobi, "4 killed, church, others burnt as religious violence breaks out in Niger", 1). Bridget Agbahime was brutally killed in Kano state on the 2 June 2016 on the ground of alleged blasphemy against Prophet Mohammed (World Watch Monitor, "Nigeria", 1). And on the 22 August 2016 on the account of alleged blasphemy against the Prophet Muhammad in Zamfara state, eight were set ablaze in a house to the total annihilation (Nwachukwu, "Blasphemy" 1).

20 Turaki, The British colonial legacy in Northern Nigeria.

21 Shadrack G. Best, "Religion and religious conflicts in Northern Nigeria." University of Jos Journal of Political Science 2, no. 3 (2001):64-81.

22 Abdulrafii Oyewumi Omotosho, "Religious violence in Nigeria - the causes and solutions: An Islamic perspective." Swedish Missiological Theme 91 no. 1 (2003):15-31. 
(2009), ${ }^{23}$ Sampson (2012), ${ }^{24}$ Adegbulu (2013), ${ }^{25}$ Mulders (2016), ${ }^{26}$ and Tuduks $(2018)^{27}$. Scholars ${ }^{28}$ have described the relationship between the two religious groups as characterized by exclusion, discrimination, marginalization, superiority/inferiority complex, inter-religious intolerance, hatred and ignorance. These characteristics are responsible for creating interreligious tension, which historically has made both adherents to suffer the consequences through gross loss of lives and property. The tense relationship creates a base for recurrent violence as a result of continued reprisal across the groups. ${ }^{29}$ The result of this broken relationship is that religious places of worship and other common institutions ${ }^{30}$ in society are used with fear of an outbreak of an attack. Isaac Terwase Sampson reveal evidences of such religious attacks especially in churches and mosques in the region. ${ }^{31}$ The reasons of each other's fear and the practice of dysfunctional relationship

23 Yushau Sodiq, "Can Muslims and Christians live together peacefully in Nigeria?" The Muslim World 99 no. 4 (2009):646-688.

24 Isaac Terwase Sampson, "Religious violence in Nigeria: Causal diagnoses and strategic."

25 Femi Adegbulu, "Boko Haram: the emergence of a terrorist sect in Nigeria 2009-2013." African Identities 11, no. 3 (2013):260-273.

26 Arne Mulders Crushed but Not Defeated: The Impact of Persistent Violence of the Church in Northern Nigeria (Open Doors and Christian Association of Nigeria, 2016). [Online]. Available: https://www.opendoorsuk.org/about/how-we-help/advocacy/ nigeria-report-12 [20 April 2019].

27 Tuduks, "(Dis-)continuity of Colonial Religious Identities."

28 Such as Best, "Religion and religious conflicts in Northern Nigeria."; Omotosho, "Religious violence in Nigeria"; B. Kwashi, "Conflict, suffering and peace in Nigeria." Transformation 21, no. 1 (2004):60-69. (2004), Sodiq, "Can Muslims and Christians live together peacefully in Nigeria"; J.D. Gwamna, Religion and politics in Nigeria (Jos: African Christian Textbooks, 2010); M. A. Ojo \& F.T. Lateju, "Christian-Muslim conflicts and interfaith bridge-building efforts in Nigeria." The Review of Faith \& International Affairs 8 no. 1 (2010):31-38; Y. Turaki, Theory and practice of Christian missions in Africa: A century of SIM/ECWA history and legacy in Nigeria 1893 - 1993. Vol. 1 (Nairobi: IBS Press, 1999); Y. Turaki, Tainted Legacy: Islam, Colonialism and Slavery in Northern Nigeria (McLean: Isaac Publishing, 2010); Sampson, "Religious violence in Nigeria: Causal diagnoses and strategic"; I Bitrus, "The Persecution of the Church in Northern Nigeria: A Theological Response." Word \& World 36 no. 4 (2016):380-389; Mulders, Crushed but Not Defeated.

29 Hussaini Abdu, Clash of identities: State, society and ethno-religious conflicts in Northern Nigeria (Kaduna: Dev Reach, 2010), 220; cf. Sampson, "Religious violence in Nigeria: Causal diagnoses and strategic," 107-112; Tuduks, "(Dis-)continuity of Colonial Religious Identities," 180.

30 Such as educational institutions (mostly secondary schools and post-secondary institutions), malls, commercial banks, public motor vehicle stations,

31 Sampson, "Religious violence in Nigeria: Causal diagnoses and strategic," 107-112. 
among the two religious groups have caused Christians and Muslims to live in segregated areas in Northern Nigeria. ${ }^{32}$

According to Bruce and Yearly, ${ }^{33}$ dysfunctional relationship depicts activities in relationship that are injurious to a society or activity that has harmful or unpleasant consequences. In the context of inter-religious coexistence, dysfunctional relationship results in an encapsulated mind-set that allows a religious group to comfortably live in the world of "we/us" and "them/they" (Augsburger 1986:22). This worldview indicates a categorical line drawn between the two religious groups. In an exclusive community, the people's inclusive lifestyle promotes the pronouncement of "we" and "us", different from "they" and "them". The inter-religious discrimination and exclusion further reveals the state of superiority and inferiority complexes among the two religious groups. ${ }^{34}$ This situation where a religious group sees itself as superior over the other triggers tension and inter-religious crisis.

Yushau Sodiq, a Nigerian Islamic scholar agrees with the state of Christian/ Muslim dysfunctional relationship which result from mistrust and conflict. ${ }^{35}$ He described the causes of tension as multiple but stressed the superiority/ inferiority complex as primary source where each religious adherent considers its religion as superior. Yushau Sodiq reveals that even though the Christian and Muslim missionaries did not express explicitly that each other's religion is inferior, nonetheless it is implied in their enterprises. ${ }^{36}$ However, he admits that the dysfunctional relationship triggers violence

32 For example, in Jos the capital city of Plateau sate, places like, Anguwan Rogo, Bauchi Road, Rikkos, and Gangare are Muslim exclusive communities, while Apata, Anguwan Rukuba, Jenta Adamu, Rukuba Road, and Utan are Christian exclusive communities. In Kaduna metropolis, the Christian exclusive communities include Television, Saban Tasha, Narayi, Kamazo, Gbagyi Villa, Gonin Gora, and Anguwan Sunday. The Muslim exclusive communities are Rigasa, Tudun Wada, Anguwan Dosa, Badarawa, Kawo, Rigachukun,Mararraban Jos, Anguwan Sarki, Anguwan Kanawa, Abakuwa among others. In some of these religious exclusive areas, it is dangerous for a member of one religious group to be seen in the community of another at an odd time

33 Bruce and Yearly, The Sage Dictionary of Sociology, 79.

34 Tuduks "(Dis-)continuity of colonial religious identities," 182.

35 Sodiq, "Can Muslims and Christians Live Together Peacefully in Nigeria?" 655.

36 Ibid., 656. 
among the Christians and Muslims in Northern Nigeria with the latter pointed as the more intolerant group:

When it comes to violence there are more reports and records of Muslim violence, especially in the North. This indicates a lack of tolerance among the Muslims there. Ninety percent of reported religious violence occurred in the North, particularly in the areas where the Sharia law is in operation ${ }^{37}$.

The distinct religious identities in the form of superiority/inferiority complex was argued as originating in the British colonial era. ${ }^{38}$ According to Yusuf Turaki, ${ }^{39}$ Islam was the only religion favoured in the colonial administration; as such, the adherents lived under the privileged status of superiority, while non-Muslim were considered as inferior, addressed pejoratively as "arna", ${ }^{40}$ and the colonial administration referred to as the "Pagan Administration". Turaki blames the colonial administration for the distinct identities among the religious groups who were developed and nurtured separately and in isolation of each other. Consequently, since these colonial times, Muslims and Christians relations are shrouded in religious and cultural intolerance which manifest in inter-religious crises today. The effect of the colonial administrative stratification has been confirmed in the report of the International Joint Delegation of the World Council of Churches (WCC) and the Royal Aal al-Bayt Institute for Islamic Thought as one of the causes of inter-religious tensions and crises in Northern Nigeria. ${ }^{41}$ In view of these inter-religious challenges, there is a need for pragmatic response to which healing and reconciliation would make a great contribution in addressing the traumatic state of these groups.

37 Ibid., 659

38 The colonial religious policy responsible for the institution of distinct identities among the religious groups is discussed in Tuduks "(Dis-)continuity of colonial religious identities."

39 Turaki, The British colonial legacy in Northern Nigeria, 189.

40 "Arna" is a Hausa word referring to pagans, its singular form is "arne". The term "arne" (singular) is sometimes used interchangeably with Kafir (Arabic) which means infidel. The two terms are mostly used by Muslims to describe non-Muslims.

41 The Royal Islamic Strategic Studies Centre, Report on the Inter-Religious Tensions and Crisis in Nigeria of the International Joint Delegation of the World Council of Churches and the Royal Aal al-Bayt Institute for Islamic Thought (World Council of Churches, 2012), 9. [Online]. Available: https://www.oikoumene.org/en/resources/documents/ wcc-programmes/interreligious-dialogue-and-cooperation/accompanying-churchesin-conflict-situations/report-on-the-inter-religious-tensions-in-nigeria [02 May 2017]. 
As theological concepts, healing and reconciliation refer to the restoration of relationship. Healing and reconciliation are two different concepts that need to be understood together in order to attain their meaning. The former has implications for the latter, as there cannot be true reconciliation without healing. According to Genevieve Parent, the danger of neglecting or marginalizing healing could lead to the hindering and undermining of reconciliation. ${ }^{42}$ Healing points to the restoration of what is lost and the demand for integration and identity. It also means regaining lost or attaining new coping skills, or even reframing existing concepts or ideas. ${ }^{43}$ Theologically, pastoral healing is faith care displayed as life care, resulting in a state of health which Daniel Louw argues is a pastoral redefinition of a sense of meaning that empowers humans to have hope - a sense of human dignity that encourages being human. ${ }^{44}$ Thus, pastoral health is the strength that enables humans to exist in the light of God's co-existence that is being-with. To the meaning of health, John de Gruchy notes that it requires the Christian understanding of being healthy or the purpose of health. ${ }^{45} \mathrm{He}$ stressed Moltmann's point that the understanding of being healthy varies greatly in the course of human history, and that not all definitions are necessarily healthy in themselves. De Gruchy asserts that the meaning and goal of life aids the understanding of what being healthy is. Therefore, health is described as that which enable people to be fully human in relation to themselves, their society and their environment. "Being human is equated with being healthy", as such the understanding of healing must mean what it implies to be human, which is against the odds of social injustice that are hazardous to health. ${ }^{46}$

On the other hand, reconciliation is a contentious and ambiguous term, that is confronted with many debates. It is a term loaded with theological and political meaning with historical legacy, yet John De Gruchy warns that the theology and politics of reconciliation should not be confused to avoid getting into futile quest that cannot be fulfilled, but rather to

42 Parent, "Peacebuilding, Healing, Reconciliation" 382.

43 Lartey, In living colour, 60.

44 Louw, "The healing dynamics of space." 2013.

45 De Gruchy, "Salvation as healing and humanization", 43.

46 Ibid., 44. 
explore their connections. ${ }^{47}$ The contesting voices have made people speak of reconciliation that is "true" or "real" or "authentic", which implies that there are some forms of reconciliation that are "cheap" or "false" and fake. ${ }^{48}$ This suggests that reconciliation cannot be simplified by short-cutting at the expense of the hermeneutical process. The purpose of reconciliation is to bring people together and to bridge the gap created by a lack of forgiveness. ${ }^{49}$

In reconciliation, it must be realized that for it to be made possible, there is a need to understand that there is a process, which is pastoral and filled with risk, as one could be exposed, misled, misunderstood or offended.$^{50}$ It is a journey from the past through to the future, a journey from a state of alienation to communion. ${ }^{51}$ Katongole and Rice added that it is a journey from "old" to "new" calling for great skilfulness and discipline, of which the most crucial is memory. ${ }^{52}$ The healing of memory is critical in reconciliation. It involves attending to both victims and offenders, listening and hearing their confessions. Michael Lapsley and Stephen Karakashian asserts that the following questions are very important to the life of an individual and the nation's history as well: What have you done? What was done to you? What did you fail to do? ${ }^{53}$ The three questions imply that one could be a perpetrator and a victim as well. It may be realized that offences are shared by way of commission, omission or reprisal when participants are sincere in responding to the three questions. The questions indicate that both victims and perpetrators constitute part of one another's stories. ${ }^{54}$

Reconciliation happens when the two parties are on the same platform, which allows for a true release of remorse and confession, resulting in the offer of forgiveness. Healing and reconciliation are thus crucial for

47 De Gruchy, Reconciliation, 15.

48 Conradie, "Reconciliation as one guiding vision for South Africa?" 14.

49 Lartey, In living colour, 60-68.

50 Thesnaar, "Facilitating healing and reconciliation with young people", 39.

51 De Gruchy, Reconciliation, 28.

52 Katongole and Rice, Reconciling all things, 49.

53 Lapsley and Karakashian, Redeeming the Past: My Journey from Freedom Fighter to Healer, 196.

54 Thesnaar, "Healing the scars", 30. 
addressing the past inter-religious crises that have created a deep-rooted trauma and a dysfunctional relationship among Christians and Muslims in Northern Nigeria. The state of Christian/Muslim inter-religious relationship has been empirically studied through an in-depth interview to examine the contextual experience of the religious groups in Northern Nigeria. The next section describes the methodology used in administering this empirical study.

\section{Methodology}

To administer the empirical study, the research design used interview as its method of data collection. The choice was motivated by the interest of qualitative research of drawing an in-depth knowledge and experience of the people. ${ }^{55}$ The qualitative research enables the researcher to strive towards understanding the people in accordance to their worldview. ${ }^{56}$ Therefore, the research made use of an in-depth inquiry to achieve the depth of knowledge in the task of qualitative research. ${ }^{57}$ The interview was planned through the gatekeepers ${ }^{58}$ who issued the permission to engage the religious leaders as research participants. The preparation included agreeing on the schedule of the interview and signing of the consent form.

The interview questions were in accordance with the research unit of evaluation of analysis. ${ }^{59}$ The selection of the unit of evaluation was guided by the goal of the study which is the investigation of the context of

55 Ranjit Kumar, Research Methodology: A step-by-step guide for beginners (3rd edition. London: Sage, 2011), 192.

56 Johann Mouton, How to succeed in your Master's \& Doctoral Studies: A South African guide and resource book (Pretoria: Van Shaik Publishers, 2001), 194.

57 Elizabeth Henning, Wilhelm Van Rensburg, and Brigitte Smit, Finding your way in qualitative research (Pretoria: Van Schaik Publishers, 2004), 3.

58 These refers to the two religious organizations: the Christian Association of Nigeria $(\mathrm{CAN})$ and the Jama'atu Nasril Islam (JNI). Whereas CAN is the Christian organization that unites all members in the country, JNI is a Muslim organization that unite Muslims in Nigeria.

59 The unit of analysis refers to the question of interest of the researcher that warrant for investigation in a study and can also be understood as units of observation or those things that a researcher examines; Earl Babbie and Johann Mouton, The Practice of Social Research (Cape Town: Oxford University Press, 2001), 84, 85. 
Christian/Muslim co-existence in Northern Nigeria. There were four units of evaluation as follows reflecting the interview research questions:

- Investigation of the challenge of Christian/Muslim co-existence in Northern Nigeria.

- Description of the extent and effects of the challenge of Christian/ Muslim co-existence in Northern Nigeria.

- Evaluation of the role of religious leaders in addressing the challenge of Christian/Muslim co-existence in Northern Nigeria.

- Suggestion for means of intervention towards addressing the challenge of Christian/Muslim co-existence in Northern Nigeria.

The population of the study includes all the religious leaders in the region of Northern Nigeria. However, because the capacity was too large to handle, sampling was necessitated for efficient and realistic research. In the sampling process, the criteria of diversity were used in enabling the recruitment of participants who represented a variety of positions that are relevant to the research topic.60 Three sampling frames were considered. The first was the use of the three geo-political zones of Northern Nigeria, where three states were randomly selected: Kaduna State from north-west zone, Plateau State from north-central, and Gombe State from northeast. The second sampling frame used was religious organisations with the consideration of the heads of the religious leaders. These comprised the three states chairmen of Christian Association of Nigeria (CAN) and Jama'atu Nasril Islam (JNI), and the three state coordinators of Christian Religious Studies (CRS) and Islamic Religious Studies (IRS). Therefore, there were six CAN \& JNI chairmen, and six CRS \& IRS coordinators giving a total of twelve heads of religious leaders.

The third sampling frame was the use of religious leaders that included Pastors, Imams, and Christian \& Islamic religious teachers. In using this frame, random sampling was applied where nine Pastors, nine Imams, nine Christian religious teachers, and nine Islamic religious teachers from the three states were selected making a total number of 36 religious leaders.

60 Nigel King and Christine Horrocks, Interviews in Qualitative Research (London: Sage, 2010), 29. 
Altogether, there were 48 sampled research participants. ${ }^{61}$ The table below gives the codes representation for the empirical study.

\begin{tabular}{|l|l|l|}
\hline State & Category & $\begin{array}{l}\text { Number of } \\
\text { Respondents }\end{array}$ \\
\hline $\mathrm{J}=$ Kaduna & $\mathrm{R}=$ Respondent & JR1 - JR16 \\
\hline $\mathrm{B}=$ Plateau & $\mathrm{R}=$ Respondent & BR17 - BR32 \\
\hline $\mathrm{F}=$ Gombe & $\mathrm{R}=$ Respondent & FR33 - FR48 \\
\hline
\end{tabular}

The study was conducted with the help of two research assistants from each religious group. The research assistants facilitated the meeting with the research participants and were also involved in follow-up appointments. After the interview was completed, the row data were transcribed into written texts by a language specialist. The texts were further analysed using a thematic analysis method ${ }^{62}$ through the steps of coding and categorisation with ATLAS.ti software that facilitated the process. Themes emerged from the data codes and categorisation. As to what counts as themes, Virginia Braun \& Victoria Clarke describes a theme as capturing important part of the data that is relevant to the research question presenting some level of patterned meaning within the data set. ${ }^{63}$ Braun \& Clarke assert that the crucial state of a theme is not necessarily dependent on quantity but on whether it captures importantly something related to the overall research question.

There are four units of evaluation that produced the same number of interview questions. Each unit of evaluation is followed with the corresponding question and themes that emerged from the responses. These are presented below.

61 A consent form was signed by each respondent indicating a clear statement of confidentiality of information. This concurs with the interest of the research which is not causality where it highlights the respondents' identities, but it is hermeneutical as it seeks to understand what is happening and making a pragmatic contribution.

62 A thematic analysis is a method of identifying, analysing and reporting patterns within data (Boyatzis, 1998:16). The result gives an organized description of data in a somewhat rich detail (Virginia Braun \& Victoria Clark, "Using Thematic Analysis in Psychology." Qualitative Research in Psychology 3 no. 2 (2006):79).

63 Braun and Clark, "Using Thematic Analysis in Psychology," 82. 


\section{1st Unit of evaluation:}

Investigation of the challenge of Christian/Muslim co-existence in Northern Nigeria.

\section{Question:}

What are the challenges of Christian/Muslim co-existence in Northern Nigeria?

\section{Themes that emerged from the responses:}

Theme 1: Inter-religious ignorance has made individuals and or groups to consider adherents of other religious groups with hatred.

Theme 2: Lack of inter-religious understanding that results to intolerance and favouritism among the two religious groups.

Theme 3: Social and religious distinct identities among the religious groups is affecting inter-religious cordial relationship.

Theme 4: Religion is manipulated by religious and political leaders for personal or group interest.

Theme 5: Inter-religious ignorance makes both adherents vulnerable and accessible by enemies of unity.

Theme 6: Inter-religious ignorance can produce and maintain constant reoccurrence of sad events among the religious groups.

Theme 7: Inter-religious ignorance has made the religious adherents to keep confusing crises of ethnic, political and religious together thereby allowing religion to control all the crises.

Theme 8: Social media has been misused to spread inter-religious ill information that triggers more tension among the adherents.

Theme 9: Struggle for dominance as challenge of Christian/Muslim relationship is seen as another form of Jihad against the Christians. Theme 10: Claim of a geographical location by one religious group made the other aliens thus not given citizenship.

Theme 11: Religious fanaticism and extremism would not allow the relationship between Christians and Muslims to be cordial.

Theme 12: Lack of exposure to the reality of inter-religious understanding has made some religious leaders to mislead religious adherents into engaging in contrary things from what religious books teach.

Theme 13: Some religious adherents are both illiterate and ignorant of the 
religious knowledge and therefore are often mislead.

Theme 14: Some pseudo-religious leaders are half-baked with the knowledge of the religion which they preach and teach. Therefore, they preach and teach their members only what they know and believe.

\section{2nd Unit of evaluation:}

Description of the extent and effects of the challenge of Christian/Muslim co-existence in Northern Nigeria.

\section{Question:}

How would you describe the extent and effects of the challenges of Christian/Muslim co-existence in Northern Nigeria?

\section{Themes that emerged from the responses:}

Theme 1: Youths are abused for personal political interest as they are often misused as tools for causing political and religious crises.

Theme 2: An individual or group that is self-centred has injustice as a common attribute in dealing with different people in the community. Theme 3: Discrimination among Christians and Muslims is very common to the extent that even residential quarters are polarized.

Theme 4: Christians and Muslims live with fear and suspicion of each other so that trust is completely lost amongst them.

Theme 5: The relationship between Christians and Muslims is likened to a Hausa adage "Zaman Doya da Manja ake yi".

Theme 6: The effects of the challenges among the religious groups keep triggering and resulting to violent crisis.

\section{3rd Unit of evaluation:}

Evaluation of the role of religious leaders in addressing the challenge of Christian/Muslim co-existence in Northern Nigeria.

\section{Question:}

What are the leaders' contributions in addressing the challenge of Christian/Muslim co-existence in Northern Nigeria?" 


\section{Themes that emerged from the responses:}

Theme 1: Religious Leaders are proactive and ensure that the situation is doused in the event of crisis.

Theme 2: There are good and bad leaders in this regard, while the good are making positive efforts, the bad sabotage it.

Theme 3: Some religious leaders are cowards they cannot advocate the truth for fear of been arrested by government. And because of the fear, the two religious bodies: CAN and JNI are not united together in the pursuit of common goals.

Theme 4: Religious leaders have abused and compromise their work by putting much desire on materialism and sometime been used by politicians as campaign agents.

Theme 5: The approaches such as teaching and preaching for addressing the challenges are applauded for others but for some it is simply hypocritical.

Theme 6: The strategy of holding meetings and reporting crisis to security agents are not enough and should not just be relied upon.

Theme 7: Some leaders are selfish and do not have the fear of God and the interest of the unity of the religious groups.

\section{4th Unit of evaluation:}

Suggestion for means of intervention towards addressing the challenge of Christian/Muslim co-existence in Northern Nigeria.

\section{The question:}

What would you suggest as possible ways of addressing the challenges of Christian/Muslim co-existence in Northern Nigeria?

\section{Themes that emerged from the responses:}

Theme 1: Avoid provocation and spread of rumours - they are incendiaries for religious violence.

Theme 2: Engage in inter-religious relationship and interaction.

Theme 3: Christian and Muslim leaders should emulate Jesus Christ and Prophet Mohammed respectively, and also be models of emulation for the religious adherents.

Theme 4: There is need for inter-religious understanding and learning among the religious groups to enhance meaningful inter-religious 
relationship and tolerance.

Theme 5: To build and encourage inter-religious respect and peaceful coexistence among members of the religious adherents, Pastors and Imams must teach members the need.

Theme 6: Obedience to the laws of the land, and inter-religious regulatory body.

Theme 7: Need for joint efforts from intentional government policy, religious policy, non-governmental organisations, and civil society organisations.

\section{Discussion}

The undermining of the inter-religious unity or the lack thereof has been identified as a factor that makes the adherents vulnerable to intruders from outside Northern Nigeria. Respondent FR33 recounts, "Negative reaction to foreign issues which happened sometimes in 2005 here in this state when somebody from another country allegedly designed a caricature of Prophet Mohammed, as a result many Christians were made scapegoat." The transfer of aggression where Christians become a scapegoat as a result of an outside generated crisis is noted by researchers such as Gwamna and Griswold. ${ }^{64}$ They identified the Northern Nigerian Christians as scapegoats of for example in the Osama Bin Laden riot (2001), the Miss World Pageant crisis (2002) and the Prophet Mohammad Cartoon crisis (2006).

Inter-religious ignorance results in hatred, intolerance, and favouritism that culminates in the struggle for dominance which ultimately produce and maintain a crisis among adherents. Inter-religious ignorance makes adherents drag other forms of crises into religion. ${ }^{65}$ For example, crises generated from ethnic or tribal and political spheres have often metamorphosed into religious conflict. This state points to how religion has permeated tribal and political spheres in people's life. A respondent expressed the view as follows:

64 Gwamna, Religion and politics in Nigeria, 64-66; Eliza Griswold, "Christian-Muslim encounters in Nigeria on the fault line." Christian Century 127, no. 22 (2010):22-25.

65 Mohammed Usman, "Religion and violence in Nigeria: 1980-2012." Bangladesh e-Journal of Sociology 10 no. 2 (2013):41-51. 
What I consider challenge of Christian/Muslim relationship is the interference of two different things into religion which is politics and tribalism. But religion has caused no problem whether Christianity or Islam. They do not pose any problem at all; it is the interference of politics and tribalism that have brought challenges between the two religions (BR24).

This state indicates the fluid relationship between the socio-political and religious. In the report on the inter-religious tensions and crisis in Nigeria, Prince Bola Ajibola, a member of the international joint delegation of the World Council of Churches and the Royal Aal al-Bayt Institute for Islamic Thought indicates that "In Nigeria, three things are intertwined; religion, politics and ethnicity and the three are beclouded with corruption, poverty and insecurity. It is therefore difficult to solve one without considering all other underpinning factors". ${ }^{66}$ This explains the view that religion has permeated the lives of every Northern Nigeria citizen, so that it is difficult to live in a secular state.

Social media as a challenge to Christian/Muslim inter-religious coexistence was stressed in the way it is misused in spreading inter-religious ill information that triggers tension among the adherents. Social media is one of the public platforms where people express their views. In some cases, sensitive issues that pertain to religions are aired out, and the immediate neighbours becomes victims of scapegoating. According to Sampson, ${ }^{67}$ "provocative and inciting utterances, sensational journalism, political manipulation of religion, incitement in the social media and mobile telephony, among others, are key causes of religious violence in northern Nigeria."

The extent and effects of the challenges are alarming on how, for example, the youths are used as tools in generating and escalating political and religious crises, and the youths are ultimately the victims of the same crisis. While youths are supposed to be employed and given opportunity to explore their potential, they are unfortunately abused by both political and

66 The Royal Islamic Strategic Studies Centre, Report on the Inter-Religious Tensions and Crisis in Nigeria, 9.

67 Sampson, “Religious violence in Nigeria: Causal diagnoses and strategic," 112. 
religious leaders for individual or religious group interest. The youth in the Nigerian context are people between the ages of 18 and 35, who are citizens of the Federal Republic of Nigeria. ${ }^{68}$ According to Ononogbu, ${ }^{69}$ the youths described by the Federal Republic of Nigeria constitute about 60 per cent of the country's population. A range of socio-religious groups, terrorist cells, public and opinion leaders, including politicians, religious and even military leaders and governments, have been implicated as those that abuse the availability of the youth to carry out violent conflicts in Nigeria. ${ }^{70}$ The youth consider their involvement in the acts of perpetration as means of earning a living since they are mostly unemployed.

The effects of the challenge of inter-religious co-existence include discrimination to the extent that even residential quarters are polarized. Discrimination is often directed to the minority group in a society. In this regard, a respondent stated that:

We see ourselves as enemies. Muslims do not trust me, and I don't trust them, whereas it was not like this before - we used to sit, eat and converse together but now, especially here in this state, we are separated - northern part Muslim dominated, and southern part dominated by Christians. We no longer benefit from each other as before (JR4).

Discrimination and exclusion against the Christian minority in Northern Nigeria was reported to the United Nations Human Rights Council by the Christian Solidarity Worldwide where areas such as employment, access to education, provision of public services, were outlined. ${ }^{71}$ The research of Arne Mulders on the state of Christian/Muslim co-existence in Northern Nigeria reiterates the practice of discrimination in employment and

68 National Youth Development Policy. National Youth Policy: Federal Government of Nigeria (2001), 4. [Online]. Available: https://www.slideshare.net/gochi360/nationalyouthpolicy2009 [22 February 2018].

69 David C. Ononogbu, "The Youth and Socio-Religious Conflicts in Africa: The Nigerian Dynamics (2017)." Conference Paper in Research Association for interdisciplinary studies, RAIS, 13.

70 Ononogbu, "The Youth and Socio-Religious Conflicts in Africa," 15-16.

71 Christian Worldwide Solidarity, "Briefing: Nigeria, Submission to United Nations Human Rights Council Universal Periodic Review (2008),” 4-8. [Online]. Available: http://lib.ohchr.org/HRBodies/UPR/ Documents/Session4/NG/C SWNGAUPR S42009anxFull Report.pdf [01 June 2017]. 
promotion among Christian and Muslim candidates with preference given to the latter. ${ }^{72}$ In a similar practice, Muslims were reported to have been discriminated by the Christian majority in the Plateau State of Northern Nigeria which was understood as one of the causes of religious crisis in the state. ${ }^{73}$ The issue of discrimination and exclusion is thus motivated by the majority/minority contest.

As a result of the state of inter-religious ignorance that produces hatred, intolerance, favouritism, struggle for dominance, and recurrent crisis, Christian/Muslim relationship is described by respondent BR25 as follows: "The effects of these challenges are pretence, Christians and Muslims are just living but not in good terms, the state of living could be likened to Hausa proverb that says 'Zaman Doya da Manja ake yi'." The proverb was formulated in the context of a cooked Yam with palm oil that does not penetrate deep inside the Yam, although the Yam seems overwhelmed with the oil. The proverb is used to mean that the unity between Christians and Muslims is only perceived as cordial but layered with hatred for each other. This proverb therefore describes the relationship as pretentious. This proverb is evident in the quotidian; regardless of religion, people work together, and share same public and social amenities yet there is an overall underlying animosity.

In addressing the challenges, religious leaders are said to be of two types: The God-fearing and the selfish religious leaders. While the former faithfully work towards addressing the challenges, the selfish leaders promote their interest by becoming part of the problems that create inter-religious tension and violence. Da'awah Institute of Nigeria echoes the presence of good and bad religious leaders because it indicates that the Qur'an (3:113; 3:75; 2:8-9) and Sunnah make it clear that not all non-Muslims are bad people, just as not all Muslims are good people. ${ }^{74}$ According to Abdulrafii Oyewumi

72 Mulders, Crushed but Not Defeated, 29.

73 Human Rights Watch, "Indigeneity and Inter-communal Conflict: Case Studies (2006)," 3. [Online]. Available: https://www.hrw.org/reports/2006/nigeria0406/7.htm [27 August 2016].

74 Da'wah Institute of Nigeria, Relations with Non-Muslims: An introductory examination of the Islamic textual evidence for peaceful inter-faith relations (Minna: Islamic Education Trust, 2009), 25. 
Omotosho, ${ }^{75}$ religious leaders are responsible for the acts of provocation that trigger religious crisis. He exemplifies that some Christian and Muslim polemics engage in provocations that are worth causing violent crisis among the two religious groups. A good number of religious leaders are united in ensuring that Christians and Muslims co-exist cordially. The two religious organizations - CAN and JNI, and individual religious leaders help in controlling issues that trigger violent crisis. The use of religious dialogue by religious leaders to control crisis and regain confidence has been noted by Je'adayibe Dogara Gwamna. ${ }^{76}$ Gwamna believes that religious leaders' efforts using religious dialogue promotes peaceful co-existence among the religious groups.

One of the examples that indicates bad leadership is pointed out by respondent JR2:

I think people are becoming accidental Imams and Pastors they are not concerned about God but the material and pleasurable aspect of it. Their minds are preoccupied with thoughts like; I will be respected, I will have these or that, I will have the command of the people and so on. All these are earthly things I wonder how the Mosque can change the psyche of whoever will want to become an Imam or a preacher, a true preacher and a sheikh and who will accept to submit himself to God almighty without naira and kobo. I don't know, because politics is becoming too dominant.

Many religious leaders have compromised their ministries with political interests because of a desire for materialism. Some pastors and imams accept being lobbied by politicians and allow themselves to be used for political campaigns. According to Benjamin C. D. Diara \& Nkechinyere G. Onah, ${ }^{77}$ materialism as an excessive quest for or pursuit of material wealth is one of the major root causes of all vices such as bribery and corruption, kidnapping, armed robbery and terrorism, prevailing in Nigerian society today. They noted that religious leaders in Nigeria have become deeply involved in the acquisition of wealth and stressed that the acquisition of

75 Omotosho, "Religious violence in Nigeria," 25.

76 Gwamna, Religion and politics in Nigeria, 46.

77 Benjamin C. D. Diara and Nkechinyere G. Onah, "Corruption and Nigeria's Underdevelopment: A Religious Approach.” Research on Humanities and Social Sciences 4 no. 4 (2014):22. 
material wealth through corrupt means has unfortunately become an intrinsic aspect of the practice of Nigerian politics. Diara \& Onah postulates that the common claim that some religious leaders use diabolical and money-making rituals to attract people to their circles may not be far from the truth. ${ }^{78}$ This consideration is because many of such deceptive leaders still draw more congregants to their places of worship. Diara \& Onah express that the prevalence of such practice is worse in Christianity, where the prosperity gospel has been on the rise and produced self-made pastors and bishops for materialistic end.

Religious leaders who compromise their pulpit ministries for material gain are often the ones who find it difficult to confront and challenge possible triggers of violence from government officials. CAN and JNI are expected to address any form of bad governance in unity to ensure the civic welfare of their religious adherents as citizens of Nigeria. Even though CAN \& JNI were primarily created for internal unity and harmony, the state of conflict that consequently affects their members implies the need for inter-religious cohesion. Therefore, there is need for cooperation among the two religious organisations to successfully address the inter-religious challenges together.

In relation to religious leaders' contribution, some responses attest to the view that some preachers teach co-existence but instigate and support violence in other gatherings. The churches and Mosques have been identified as places that hold meetings for planning evils against each other. For example, respondent JR16 says: "In my opinion, some religious leaders are just saying things verbally, but they don't mean it. But if they would show exemplary peaceful coexistence, the followers will learn better." Respondent JR4 added that

Whatever is conspired it is either from the Mosque or Church. So, whatever a Pastor tells his congregation that is what they will accept; the same thing, what the Imam tells his followers that is what they will accept and act on. So, when a leader condemns the other group his followers will do the same.

These remarks depict the contrast between what the leaders say in public and what they say in private. Some of these religious leaders have been

78 Diara and Onah, "Corruption and Nigeria's Underdevelopment," 26. 
reported by the International Joint Delegation of the World Council of Churches (WCC) and the Royal Aal al-Bayt Institute for Islamic Thought (RABIIT) as part of the causes of religious tensions and crises in Nigeria. ${ }^{79}$

Respondent JR2 suggested in support of heterogeneous society with respect to religious diversity. He states that:

Although we are in a world of individualism, you cannot live all alone by yourself. There are others and plurality are very important and even at the time we were not as sophisticated and educated as it is today, we accepted plurality why not today? We don't want a heterogeneous society but only homogeneous society where it is only of me my tribe, my colour, sometimes even my house to the exclusion of others. In various places of the Qur'an it did acknowledges plurality. If this is the teachings, that is why the coexistence was very romantic and peaceful and all were left to practice their own religions.

The support of the Qur'an has been noted in respect of plurality in the response of JR2. This has been asserted by Amyn Sajoo, ${ }^{80}$ who argues that the pluralistic position in connection to the Qur'an using a reference that points to the idea that God could have made all humanity into a single group if he had chosen to (Qur'an 5:48), implying that plurality is his will. Ayoub asserts that in such interaction, the intention of Prophet Mohammed and the Qur'an does not expect the Christians to forsake Christianity and join Islam, rather, the interest was on co-existence of the two religions. ${ }^{81}$ This could be seen in the Qur'anic ${ }^{82}$ teaching on Christian/Muslim interaction who share the same source of the revelation of religious Books

79 The Royal Islamic Strategic Studies Centre, Report on the Inter-Religious Tensions and Crisis in Nigeria, 9.

80 Amyn B. Sajoo, Muslim Ethics: Emerging Vistas (London: I.B. Tauris Publishers, 2009), 76.

81 Mahmoud M. Ayoub, A Muslim View of Christianity: Essays on Dialogue (Maryknoll: Orbis Books, 2007), 14.

82 The inter-religious dialogue motivation is found in the Qur'an: “And dispute ye not with the People of the Book ...But say, 'we believe in the revelation which has come down to us and in that which came down to you'; our God and your God is one; and it is to Him we bow" (29:46); "O people of the Book! Come to common terms as between us and you that we worship none but God; that we associate no partners with Him; that we erect not from among ourselves Lords and patrons other than God..." (3:64). 
and oneness of God). ${ }^{83}$ Similarly, Sankamo reveals that Jesus was involved in relationships with people of other religious traditions where he reached out to their needs, such as the Canaanite woman, the Centurion, and the Gerasene demoniac whose story suggests he was a Gentile. ${ }^{84}$ Both Jesus Christ and Prophet Mohammed live in a pluralistic society. To promote pluralistic lifestyle, religious adherents must engage in bridge building. Many scholars ${ }^{85}$ believe that bridge building will bring about inter-religious transformation, healing, and reconciliation.

Inter-religious understanding and learning are identified as means of promoting pluralistic community that allows for tolerance and respect for religious diversity. In this regard, there is need for both communities to learn the other's basic religious beliefs. Curriculum must be reviewed to suit such demand of inter-religious education in primary and secondary schools of both public and private institutions. This contribution is noted by respondent BR30: "There is need for curriculum constantly review to meet with the changing time, and inter-religious challenges so that our children will grow with an inter-religious understanding that will help in peaceful coexistence in their generations". Respondent JR10 similarly argues that:

I would suggest that we go back to how things were in those days where both CRS and IRS were taught to both Christian and Muslim pupils at the same time. It helps the children to grow with basic knowledge of what the two religions are all about. I would also suggest that both Christians and Muslims should interact with each other very well - we should avoid segregation.

Respondent (JR10) indicated that there was a time where the teachings of Christian Religious Studies (CRS) was given to both Christian and Muslim pupils at the same time, and Islamic Religious Studies (IRS) also taught to

83 Omotosho, "Religious violence in Nigeria," 21.

84 Juho Sankamo, Jesus and the gentiles (Finland: Abo Akademi University Press, 2012), 141.

85 For example, Abdullahi A. Abdulkadir, Falling fences and Building Bridges: A Comparative Religious Research (Kumo: Yabanya Islamic Publication Trust, 2014) and L. D. Brown, "Bridge Building for Social Transformation." Stanford Social Innovation Review 13 no. 1 (2015):34-39. 
same Christian and Muslim pupils. The continuity of such inter-religious class was affected by the challenges of Christian/Muslim relationship. The respondent therefore suggests the possibility of resuming back to the interreligious class, which he believes will bring about the process of healing and reconciliation in a state of inter-religious ignorance.

Historically, Islamic Religious education originated before the colonial era in the region through the teaching of Arabic and Islam..$^{86} \mathrm{On}$ the other hand, Christian Religious knowledge came through colonial administrations and Christian missionaries. ${ }^{87}$ During the colonial period the teaching of religious subjects was carried out separately in the communities of religious groups. There were hundreds of missionary schools and many churches in the region of Northern Nigeria by the time of national independence in I960, the development which already produced a state of hostility and suspicion between the two religious groups. ${ }^{88}$ The Muslim community did not welcome the activities of the Christian missionaries because they were in fear that their children could be converted, and again they felt the region of Northern Nigeria belonged to them. ${ }^{89}$ The Christian missionaries' educational policy designed a plan of addressing the divide between the two religious groups by translating the Bible into some languages including Hausa, the Muslims' language in Northern Nigeria. ${ }^{90}$ These efforts were through Christian/Muslim cooperation and were also advanced by the Premier of Northern Nigeria Sir Ahmadu Bello, who encouraged the Christian community that the policy of his government was to be focused on religious tolerance without religious favouritism. The Premier appreciated the work of Christian missions and promised to continue to partner with them in the educational development of the region. ${ }^{91}$

The nationalisation of missionary schools enabled public schools to offer both Christian religious education and Islamic religious education to respective religious students. Islamic religious education focused on faith

86 Ajah, "Religious education and nation-building in Nigeria." 268.

87 Ugbor, Living the future in dialogue, 40.

88 Sodiq, "Can Muslims and Christians Live Together Peacefully in Nigeria?" 650

89 Kwashi, "Conflict, suffering and peace in Nigeria." 62.

90 Ugbor, Living the future in dialogue, 54.

91 Turaki, The British colonial legacy in Northern Nigeria, 171. 
and moral principles through the teaching and reading of the Qur'an, Hadith and the Sharia (Islamic law), as a way of life. The aim of education was to equip Muslim children for adult life. ${ }^{92}$ In Christian religious studies students are taught moral lessons from the Old Testament (OT), the synoptic Gospels, and the epistles on selected themes. ${ }^{93}$ According to the National Policy on Education (NPE) revised in 2008, Christian Religious Studies (CRS) and Islamic Religious Studies (IRS) continue to co-exist in public schools as core subjects in Primary Schools. ${ }^{94}$ In Junior Secondary Schools (year $1-3$ ), the two religious subjects are core for all students, while in Senior Secondary Schools (year 4 -6), the religious subjects are core only to students of the humanities but indicated as parts of the compulsory subjects. ${ }^{95}$ In practice, religious education began to experience challenges because the privileged majority religious group made the teaching of religious education exclusive to its religious teaching.

In relation to promotion of inter-religious cordial relationship, respondent FR48 suggest as follows:

This is not the work of an individual; there should be an intentional government policy, religious policy towards that; non-governmental organizations, civil society organizations have to come on board and create a policy that would really bring healing and reconciliation. If the government is left to champion it alone it will look political and of course, politics has brought more fractions in the society today; so, the government must not do it alone. And if religious angle is left to do it alone it will still look religious and it will bring a lot of questions and suspicion that they may not be able to answer. But where all these bodies can come on board and bring out policies holistically certainly it will be very fast in achieving the desired goal.

As efforts continue in addressing the challenges, leaders are advised to avoid any form of provocation and spread of rumour as they are incendiaries for religious violence.

92 Ugbor, Living the future in dialogue, 40.

93 Ibid., 99.

94 National Policy on Education, National policy on education and 4-year strategic plan for the development of the education sector, 19-30.

95 Ibid., 19-30. 
Generally, considering the opinions in the responses ${ }^{96}$ to all questions, it could be observed that questions 1, 2 and 4 expresses agreement to the challenge of Christian/Muslim co-existence in different ways. However, opinions expressed in question 3 points to two directions: the one commends the positive contribution of religious leaders, while the other reveals their weakness. This explains the fact on the ground as argued by the Da'wah Institute of Nigeria, ${ }^{97}$ of the presence of good and bad leaders among the religious groups.

\section{How to utilise the findings for further research}

In view of the context of "theology from below", the empirical findings were utilized in making a pragmatic contribution, thus making the voice of the people on the margin count on what ought to be done in addressing the dysfunctional relationship. Given the fact that inter-religious coexistence among Christians and Muslims in Northern Nigeria has been confirmed and found to be dysfunctional, the research recommends healing and reconciliation for addressing this situation. The approach of healing and reconciliation will be carried out through practical theological methodology that entails hermeneutical processes. The hermeneutical process includes utilization of the empirical results which fits into the four tasks of practical theological interpretation suggested by Richard Osmer. ${ }^{98}$ First, the descriptive-empirical task demands for information that is relevant in understanding what is happening in a context. Second, the interpretive task through hermeneutical exercise engages in drawing theories of arts and sciences that help in understanding and explaining the reason behind the occurrence of the patterns and dynamics. Third, the normative task uses theological concepts to interpret the contexts and forming ethical norms that will guide contribution and learning from examples of "good practice". Fourth, the pragmatic task seeks to determine a strategic action in contributing to responding to the contextual challenges.

96 In view of the consent agreement and the research hermeneutical interest that is not based on cause and effect perspective, the responses are not indicated with religious identity. However, the content of the responses shows evidences that both groups agree with the challenges of the inter-religious co-existence in Northern Nigeria.

97 Da'wah Institute of Nigeria, Relations with Non-Muslims, 25.

98 Richard R. Osmer, Practical theology: An introduction (Grand Rapids: Wm. B. Eerdmans Publishing Co., 2008), 4. 
The empirical results on the first three units of evaluation that seeks the challenges, extent, and effects of Christian/Muslim co-existence contributes in addressing the descriptive-empirical task. Some of the results from the challenges and contribution of leaders addresses the interpretive task. Still some contributions from the religious leaders will help in setting norms for inter-religious good practice. Then, the unit of evaluation that seeks for ways of addressing the challenges will contribute in archiving the pragmatic task.

\section{Conclusion}

The state of the Christian/Muslim dysfunctional relationship in Northern Nigeria revealed in the literature review was confirmed in the empirical study with an alarming extent and effects that threaten with reoccurrence of violence. The empirical research participants who are also the religious leaders accept the responsibility by blaming themselves in relation to the challenges that results to crises among the two groups in the region. The leaders described themselves in two categories: the "God-fearing" and the "selfish", explaining the efforts of the latter as sabotaging the positive contribution of the God-fearing who vigorously work towards addressing the challenges.

The research revealed the situation of the people who live on the margin, discriminated and excluded from enjoying common resources. Such victims were argued to be the minority group in Northern Nigeria. However, from the state context, the victims are determined by the minority group in that state. Therefore, given the fact that not all states are dominated by same religious group, it could be summed-up that by implication that Christians and Muslims share in being victims, depending on which state they live. In this situation, the process of healing and reconciliation will give opportunity to both groups for storytelling. This will give hope especially to the people on the margin who are living with trauma.

\section{Bibliography}

Abdu, Hussaini. Clash of identities: State, society and ethno-religious conflicts in Northern Nigeria. Kaduna: Dev Reach, 2010. 
Abdulkadir, Abdullahi A. Falling fences and Building Bridges: A Comparative Religious Research. Kumo: Yabanya Islamic Publication Trust, 2014.

Adegbulu, Femi. 2013. "Boko Haram: the emergence of a terrorist sect in Nigeria 2009-2013.” African Identities, 11 no. 3 (2013):260-273.

Ajah, Miracle. "Religious education and nation-building in Nigeria." Stellenbosch Theological Journal. 1 no. 2 (2015):263-282. DOI: http:// dx.doi.org/10.17570/stj.2015.v1n2.a12

Ayoub, Mahmoud. M. A Muslim View of Christianity: Essays on Dialogue. Maryknoll: Orbis Books, 2007.

Augsburger, David W. Pastoral counselling across cultures. Philadelphia:

Westminster Press, 1986.

Babbie, Earl and Mouton, Johann. The Practice of Social Research. Cape Town: Oxford University Press, 2001.

Best, Shadrack Gaya. "Religion and religious conflicts in Northern Nigeria." University of Jos Journal of Political Science, 2 no. 3 (2001):64-81.

Bitrus, Ibrahim. "The Persecution of the Church in Northern Nigeria: A Theological Response." Word \& World, 36 no. 4 (2016):380-389.

Boyatzis, Richard E. Transforming qualitative information: Thematic analysis and code development. California: Sage, 1998.

Braun, Virginia and Clark, Victoria. "Using Thematic Analysis in Psychology." Qualitative Research in Psychology, 3 no. 2 (2006):77-101.

Brown, L. David. “Bridge Building for Social Transformation.” Stanford Social Innovation Review, 13 no.1 (2015):34-39.

Bruce, Steve and Yearly, Steven. The Sage Dictionary of Sociology. London: Sage, 2006. 
Christian Solidarity Worldwide. "Briefing: Nigeria, Submission to United Nations Human Rights Council Universal Periodic Review (2008)." CSW Nigeria. [Online]. Available: http://lib.ohchr.org/HRBodies/ UPR/Documents/Session4/ NG/C SWNGAUPR S42009anxFull Report.pdf [01 June 2017].

Conradie, Ernst M. Reconciliation as one guiding vision for South Africa? Conceptual analysis and theological reflection. In Conradie, EM. (Ed.). Reconciliation: A guiding vision for South Africa? 13-84. Stellenbosch: SUN Press, 2013.

Da'wah Institute of Nigeria. Relations with Non-Muslims: An introductory examination of the Islamic textual evidence for peaceful inter-faith relations. Minna: Islamic Education Trust, 2009.

De Gruchy, John W. Salvation as healing and humanization, in Hart, TA and Thimell, DP (eds.), Christ in our place: The humanity of God in Christ for the reconciliation of the world, 32-47. Exeter/Allison: The Paternoster Press/Pickwick Publications, 1989.

De Gruchy, John W. Reconciliation: Restoring justice. Minneapolis: Fortress Press, 2002.

Diara, Benjamin C. D. and Onah, Nkechinyere. G. "Corruption and Nigeria's Underdevelopment: A Religious Approach.” Research on Humanities and Social Sciences, 4 no. 4 (2014):21-26.

Griswold, Eliza. "Christian-Muslim encounters in Nigeria on the fault line." Christian Century, 127 no. 22 (2010):22-25.

Gwamna, Je'adayibe Dogara. Religion and politics in Nigeria. Jos: African Christian Textbooks, 2010.

Henning, Elizabeth, Wilhelm Van Rensburg, and Brigitte Smit. Finding your way in qualitative research. Pretoria: Van Schaik Publishers, 2004.

Human Rights Watch. "Indigeneity and Inter-communal Conflict: Case Studies (2006)". Human Rights Watch. [Online] Available: https:// www.hrw.org/reports/2006/nigeria0406/7.htm [27 August 2016]. 
Joseph, Yakubu and Rothfuss, Raina. "Threats to religious freedom in Nigeria: Analysis of a Complex scenario.” International Journal for Religious Freedom, 5 no. 1 (2012):73-85.

Katongole, Emmanuel and Rice, Chris. Reconciling all things: A Christian vision for justice, peace and healing. Downers Grove, Illinois: IVP Books, 2008.

King, Nigel and Horrocks, Christine. Interviews in Qualitative Research. London: Sage, 2010.

Kumar, Ranjit. Research Methodology: A step-by-step guide for beginners (3rd edition). London: Sage, 2011.

Kwashi, Benjamin. "Conflict, suffering and peace in Nigeria." Transformation, 21 no. 1 (2004):60-69.

Lapsley, Michael and Karakashian, Stephen. Redeeming the Past: My journey from freedom fighter to healer. Cape Town: Struik Inspirational, 2012.

Lartey, Emmanuel Y. In living colour: An intercultural approach to pastoral care and counselling. London: Jessica Kingsley, 2003.

Louw, Daniel J. The healing dynamics of space: Relational and systemic therapy in pastoral care to people suffering from poverty, in Couture, PD \& Miller-McLemore, BJ (eds.), Poverty, suffering and HIV/AIDS: International practical theological, 2003.

Mouton, Johann. How to succeed in your Master's and Doctoral Studies: A South African guide and resource book. Pretoria: Van Shaik Publishers, 2001.

Mulders, Arne. Crushed but Not Defeated: The Impact of Persistent Violence of the Church in Northern Nigeria (2016). Open Doors and Christian Association of Nigeria. [Online]. Available: https://www. opendoorsuk.org/about/how-we-help/advocacy/nigeria-report-12 [20 April 2019). 
National Youth Development Policy. National Youth Policy: Federal Government of Nigeria (2001). [Online]. Available: https://www. slideshare.net/gochi3 60/national-youthpolicy2009 [22 February 2018].

National Policy on Education. National policy on education and 4-year strategic plan for the development of the education sector: 2011-2015 of Prof Ruqayyatu Ahmed Rufa'I, OON Honourable Minister. Lagos: Nigeria Educational Research and Development Council, 2008.

Nwachukwu, John Owen. "Blasphemy: Killers of 8 people in Zamfara will be brought to Book - Buhari." (2016), Dailypost. Available from: Dailypost.ng/2016/08/23/blasphemy-killers-8-people-zamfara-willbrought-book-buhari [13 March 2017].

Ojo, Matthew A and Lateju, Folaranmi T. "Christian-Muslim conflicts and interfaith bridge-building efforts in Nigeria." The Review of Faith \& International Affairs, 8 no. 1 (2010):31-38.

Omonobi, Kingsley. " 4 killed, church, others burnt as religious violence breaks out in Niger.” (2016) The Vanguard. [Online]. Available: hhukuttp://www.vanguardngr.com/2016/05/4-killed-churhes-burntniger/ [13 March 2017].

Omotosho, Abdulrafii Oyewumi. "Religious violence in Nigeria - the causes and solutions: An Islamic perspective." Swedish Missiological Theme, 91 no.1 (2003):15-31.

Ononogbu, David C. “The Youth and Socio-Religious Conflicts in Africa: The Nigerian Dynamics (2017)". Conference Paper in Research Association for interdisciplinary studies, RAIS.

Osmer, Richard Robert. Practical theology: An introduction. Grand Rapids: Wm. B. Eerdmans Publishing Co, 2008.

Parent, Genevieve. Peacebuilding, healing, reconciliation: An analysis of unseen connections for Peace. International Peacekeeping, 18 no. 4 (2011):379-395. DOI:10.1080/13533312.2011.588385

Sajoo, Amyn B. Muslim Ethics: Emerging Vistas. London: I.B. Tauris Publishers, 2009. 
Sampson, Isaac Terwase. "Religious violence in Nigeria: Causal diagnoses and strategic." African Journal on Conflict Resolution, 12 no. 1 (2012):103-134.

Sankamo, Juho. Jesus and the gentiles. Finland: Abo Akademi University Press, 2012.

Sodiq, Yushau. "Can Muslims and Christians live together peacefully in Nigeria?” The Muslim World, 99 no. 4 (2009):646-688.

The Royal Islamic Strategic Studies Centre 2012. Report on the InterReligious Tensions and Crisis in Nigeria of the International Joint Delegation of the World Council of Churches and the Royal Aal al-Bayt Institute for Islamic Thought (2012). World Council of Churches. [Online]. Available: https://www.oikoumene.org/en/ resources/documents/wccprogrammes/interreligious-dialogue-andcooperation/accompanying-churches-in-conflict-situations/reporton-the-inter-religious-tensions-in-nigeria [02 May 2017].

Thesnaar, Christo H. Facilitating healing and reconciliation with young people living in the aftermath of political and cultural conflict: The challenge to the church and its youth ministry. The Journal of Youth Ministry, 2 no. 1 (2003):29-48.

Thesnaar, Christo H. Healing the scars: A theological-hermeneutical analysis of violence from the perspectives of both perpetrators and victims. Scriptura 106 (2011):26-37.

Tuduks, Oholiabs Danladi. “(Dis-)continuity of Colonial Religious Identities: A Challenge for Christian/ Muslim Coexistence in Northern Nigeria." In Identities in Flux Globalisation, Trauma, and Reconciliation, edited by Dagmar Kusa, 178-187. Bratislava: Kritika \& Kontext, 2018.

Tuduks, Oholiabs Danladi. "Healing and Reconciliation in a Dysfunctional Relationship: Towards Inter-religious Functional Relationships in Northern Nigeria." PhD dissertation, Stellenbosch University, 2019. 
Turaki, Yusufu. The British colonial legacy in Northern Nigeria: A social ethical analysis of the colonial and post-colonial society and politics in Nigeria. Jos: Challenge Press, 1993.

Turaki, Yusufu. 1999. Theory and practice of Christian missions in Africa: A century of SIM/ECWA history and legacy in Nigeria 1893 - 1993. Vol. 1. Nairobi: IBS Press, 1999.

Turaki, Yusufu. Tainted Legacy: Islam, Colonialism and Slavery in Northern Nigeria. McLean: Isaac Publishing, 2010.

Ugbor, Chizurum Ann. Living the future in dialogue: Towards a new integral and transformative model of religious education for Nigeria in the 21st century. New York: Peter Lang, 2015.

Usman, Mohammed. "Religion and violence in Nigeria: 1980-2012." Bangladesh e-Journal of Sociology, 10 no. 2 (2013):41-51.

World Watch Monitor. Nigeria: Pastor's wife killed after blasphemy accusation. (2016) World watch monitor. [Online]. Available: https:// www.worldwatchmonitor.org/2016/06/4500 305/ [13 March 2017]. 